\title{
Efektifitas kegiatan pelatihan pembuatan ovitrap DBD pada santri Pondok Pesantren Al Falah Banjarbaru
}

\author{
Tien Zubaidah*1, Juanda² ${ }^{2}$, Isnawati ${ }^{3}$ \\ 1, 2,3 JurusanKesehatan Lingkungan Poltekes Kemenkes RI Banjarmasin \\ *e-mail: arrasyidhanif@gmail.com ${ }_{2}^{1}$ juandabrawijaya@gmail.com ${ }_{2}^{2}$ isna.husaini@gmail.com ${ }^{3}$
}

\begin{abstract}
The negative impact of the insecticides usage triggers the development of new methods other than insecticides, one f them is ovitrap tools (mosquito egg traps). The use of ovitrap as part of dengue prevention efforts has proven to be easy, cheap, safe for health and environmentally friendly. Ovitrap is effective in reducing mosquito populations. The purpose of the activity is to analyze the knowledge, attitudes and actions of students in the use of ovitrap as an effort to control Aedes sp mosquito larvae after the implementation of health counseling activities and demonstrations of making Ovitrap. All students at Pondok Pesantren Al Falah Putera became the population. As many as 96 students who were willing and involved in this activity became the research sample. McNemar test showed significant results on knowledge (0.018), attitude (0.033) and action (0.00). The making and the use of Ovitrap socialization still needs to be sought in order to increase the Santri knowlwege.. It is hoped that this activity can be implemented every year as an effort to reduce the risk of dengue fever in Banjarbaru City.
\end{abstract}

Keywords: DHF, ovitrap, training effectiveness, students

\section{Abstrak}

Dampak negatif penggunaan insektisida memicu pengembangan metode baru selain insektisida yaitu penggunaan alat ovitrap (perangkap telur nyamuk). Pemakaian ovitrap sebagai bagian upaya pencegahan DBD yang terbukti mudah, murah, aman bagi kesehatan dan ramah lingkungan. Ovitrap efektif mengurangi populasi nyamuk. Tujuan kegiatan adalah menganalisis pengetahuan, sikap dan tindakan santri dalam pemakaian ovitrap sebagai upaya pengendalian jentik nyamuk Aedes sp setelah pelaksanaan kegiatan penyuluhan kesehatan dan demonstrasi pembuatan pembuatan Ovitrap Populasi dalam kegiatan ini adalah seluruh santri pada Pondok Pesantren Al Falah Putera. Sampel yang diambil sebanyak 96 santri yang bersedia dan berperan dalam kegiatan ini. Hasil uji McNemar menunjukkan hasil yang signifikan pada pengetahuan $(0,018)$, sikap $(0,033)$ dan tindakan $(0,00)$. Peningkatan pengetahuan masih perlu diupayakan melalui sosialisasi pembuatan dan pemakaian Ovitrap. Diharapkan kegiatan ini bisa dilaksanakan setiap tahun sebagai upaya pengurangan risiko DBD di Kota Banjarbaru.

Kata kunci: DBD, ovitrap, efektivitas pelatihan, santri

\section{PENDAHULUAN}

Tingginya kasus DBD di suatu wilayah sangat ditentukan oleh tingginya populasi nyamuk Aedes di suatu wilayah. Semakin padat populasi nyamuk, semakin tinggi pula risiko terinfeksi virus DBD dengan waktu penyebaran lebih cepat sehingga jumlah kasus penyakit DBD cepat meningkat yang pada akhirnya mengakibatkan terjadinya KLB penyakit DBD. Nyamuk dewasa dapat diberantas dengan fogging menggunakan insektisida (racun serangga). Melakukan fogging saja tidak cukup karena dengan fogging yang mati hanya nyamuk dewasa saja, larva nyamuk tidak mati dengan pengasapan (Kemenkes RI, 2017). Selain itu juga pengasapan menggunakan bahan insektisida organofosfat dapat menimbulkan resistensi vektor akibat dosis yang tidak tepat (Lima dkk., 2003).

Salah satu Cara pengendalian nyamuk Aedes yang berhasil menurunkan densitas vektor di beberapa negara adalah penggunaan perangkap telur (ovitrap) berupa peralatan untuk mendeteksi keberadaan nyamuk Aedes aegypti dan Aedes albopictus. Secara khusus, ovitrap digunakan untuk mendeteksi manifestasi nyamuk ke area baru yang sebelumnya pernah dibasmi. Alat ini dikembangkan oleh Fay dan Eliason pada tahun 1966 dan disebarluaskan oleh CDC (Polson dkk., 2002). 
Untuk memaksimalkan ovitrap dalam pengendalian vektor Aedes, maka dilakukan beberapa modifikasi terhadap ovitrap. Zeichner \& Perich, (1999) telah memodifikasi ovitrap menjadi perangkap nyamuk yang mematikan (lethal atau autocidal ovitrap) dengan menambahkan beberapa jenis insektisida pada media bertelur (ovistrip) dengan efektifitas 45 $100 \%$. Sithiprasasna dkk., (2003) memodifikasi ovitrap menjadi perangkap jentik-auto dengan memasang kassa nylon tepat pada permukaan air. Untuk menarik penciuman nyamuk datang ke ovitrap yang telah dimodifikasi menjadi lethal ovitrap (LO) digunakan atraktan. Hal ini dilakukan oleh Zubaidah, Erminawati, \& Ratodi, (2020), didapatkan hasil bahwa terdapat perbedaan konsentrasi atraktan dan warna ovitrap memberikan pengaruh yang signifikan dalam menarik Aedes sp untuk bertelur. Konsentrasi 0\% (tanpa atraktan) memiliki perbedaan yang signifikan dengan konsentrasi 10\%, 20\% dan 30\% dalam menjebak telur Aedes sp. Ovitrap tanpa warna secara signifikan juga berbeda dengan ovitrap berwarna hitam dan hijau dalam menjebak telur nyamuk Aedes sp.

Ovitrap sudah dijual bebas Akan tetapi masih banyaknya masyarakat yang belum tahu tentang alat tersebut dan harganya yang mahal menyebabkan penggunaan alat tersebut tidak maksimal serta cenderung memilih metode lain seperti fogging(Kurniawati, Sutriyawan, \& Rahmawati, 2020). Oleh karena itu, dibutuhkan penyuluhan dan pelatihan tentang manfaat dan cara pembuatan perangkap telur nyamuk (Ovitrap). Ovitrap berarti perangkap telur (ovum = telur, trap= perangkap) terbukti menekan pertumbuhan nyamuk hingga 50\% (Latifa, Arusyid, Iswidaty, \& Sutiningsih, 2013).

Bahan yang digunakan dalam pembuatan ovitrap berasal dari botol plastik bekas seperti botol air mineral. Bahannya sangat mudah ditemukan dan hal ini juga bertujuan untuk mengurangi volume sampah plastik. Selain itu, Cara pembuatannya sangat sederhana dan bisa dilakukan oleh siapa saja. Hal ini dimaksudkan sebagai bagian meningkatkan literasi kesehtan terhadap bahaya DBD dan oencegahannya. Dalam konteks pendidikan pesantren maka santri memainkan peran yang penting dalam meningkatkan literasi kesehatan, baik bagi teman sebaya maupun ke masyarakat luas (Asniar, Kamil, \& Mayasari, 2020) sekaligus sebagai komponen penting dalam pemberdayaan masyarakat dan promosi kesehatan (Wiguna dkk., 2021)

Berdasarkan paparan tersebut, tujuan dari kajian ini adalah untuk menganalisis hubungan antara pengetahuan dan sikap santri dalam perilaku pengendalian vektor DBD melalui pembuatan ovitrap. Kegiatan ini diharapkan dapat bermanfaat bagi komunitas sekolah untuk memberi gambaran informasi perilaku pencegahan DBD pada santri, sedangkan bagi tenaga kesehatan diharapkan dapat menjadi masukan untuk upaya promosi kesehatan khususnya dalam rangka pencegahan DBD sekolah.

\section{METODE}

Penelitian ini dilaksanakan di Pondok Pesantren Al Falah Putera Kota Banjarbaru, Kalimantan Selatan. Jenis penelitian yang digunakan adalah penelitian eksperimen semu (Quasi experiment). Populasi dalam penelitian ini adalah seluruh santri pada Pondok Pesantren Al Falah Putera Kota Banjarbaru. Adapun sampel pada penelitian ini yakni sanri pada kelas VIII dan IX dengan jumlah santri sebanyak 96 orang.

Data primer dikumpulkan melalui kuisioner untuk mengetahui kondisi awal santri tentang pengetahuan, sikap dan tindakan mengenai DBD. Instrumen yang digunaan berupa kuesioner tertutup. Selanjutnya metode kegiatan yang dilakukan untuk tercapainya tujuan program ini adalah metode ceramah, pemutaran video, diskusi dan konsultasi, kemudian demonstrasi pembuatan ovitrap dengan menggunakan botol plastik air mineral sebagai landasan untuk menentukan posisi pengetahuan santri tentang cara pembuatan ovitrap. Selanjutnya, pelatihan pembuatan ovitrap berdasarkan langkah-langkah yang telah didemonstrasikan, dan penempatan perangkap nyamuk hasil pelatihan sebagai langkah aplikasi pengetahuan yang telah dibagikan 
Alat dan bahan utama yang digunakan dalam praktek pembuatan ovitrap berupa Botol plastik air mineral dikumpulkan dari limbah rumah tangga. Ini bertujuan untuk memberikan pembelajaran kepada masyarakat bahwa sampah plastik masih bisa digunakan kembali (reuse) dan mengurangi volume sampah plastik. Adapun alat dan bahan yang digunakan yaitu botol air mineral $1500 \mathrm{ml}$, kain kasa, air mineral, benang, cat hitam, kuas, plaster, gunting, catter.

Langkah-langkah pembuatan ovitrap sebagai berikut:

1. Siapkan alat dan bahan berupa gunting, tali/benang, botol plastic air mineral, plater, kuas, cat, kain kasa dan air. Gunting bagian atas plastik sekitar 10-15 cm dari bibir botol.

2. Ikat kain kasa pada bibir botol, setelah itu lekatkan pada bagian botol

3. Gunakan perekat untuk merekatkan botol dan penutunya.

4. Cat seluruh permukaan botol dengan cat warna hitam lalu dikeringkan

5. Setelah kering, masukkan air yang berisi aktraktan berupa larutan terasi ke dalam botol tersebut sampai menyentuh kain kasa.

6. Pasang perangkap tersebut pada tempat yang sering dihinggapi oleh nyamuk.

Tim peneliti kemudian melakukan Pre Post test tentang DBD untuk melihat perubahan katagori pengetahuan, sikap dan tindakan sebelum dan sesudah kegiatan. Analisis data dilakukan dengan pendekatan deskriptif dengan tabel frekuensi dan tabel Uji crosstab dipakai untuk melihat kebermaknaan sebelum dan setelah dilakukan kegiatan. Uji McNemar dilakukan untuk pengujian statistik yang digunakan dalam menentukan apakah terdapat perbedaan yang signifikan atara variabel dependen (Adiputra dkk., 2021)

\section{HASIL DAN PEMBAHASAN}

Antusiasme peserta sangat tinggi dalam mengikuti kegiatan ini. Kegiatan penyuluhan dilakukan di dalam masjid dan saat praktek pembuatan perangkap nyamuk dilakukan di aula masjid. Hasil kegiatan pelatihan pembuatan ovitrap pada santri putra Al Falah Banjarbaru dapat terlihat pada pengukuran aspek pengetahuan, sikap dan tidnakan dari para santri terhadap pemberantasan DBD dengan metode ovitrap, seperti yang ditampilkan pada tabel 1.

Tabel 1. Hasil Pre dan post test tentang DBD pada Santri Kelas VIII dan IX Pondok Pesantren Al Falah Putera Kota Banjarbaru

\begin{tabular}{llcccc}
\hline Variabel & Kategori & \multicolumn{2}{c}{ Pretest } & \multicolumn{2}{c}{ Postest } \\
& & $\mathrm{N}$ & $\%$ & $\mathrm{~N}$ & $\%$ \\
\hline Pengetahuan & Baik & 37 & 38,5 & 85 & 88,5 \\
\multirow{3}{*}{ Sikap } & Cukup & 59 & 61,5 & 11 & 11,5 \\
\multirow{3}{*}{ Tindakan } & Baik & 80 & 83,3 & 91 & 94,7 \\
& Cukup & 16 & 16,7 & 5 & 5,3 \\
& Baik & 32 & 33,3 & 88 & 91,7 \\
& Cukup & 64 & 66,7 & 8 & 8,3 \\
\hline
\end{tabular}

Dari hasil tersebut diketahui bahwa sebagian besar santri memiliki sikap yang cenderung terkatagori baik terhadap masalah nyamuk demam berdarah dengue, sedangkan untuk pengetahuan dan tindakan pencegahan DBD masih kurang memadai. Penelitian OLEH Pujiyanti, Pratamawati, \& Trapsilowati, (2016) menyebutkan bahwa sikap terbukti secara signifikan berhubungan dengan perilaku pengendalian vektor yang dilaksanakan oleh siswa pada sekolah dasar di Kecamatan Tembalang, Semarang. Hal ini berarti bahwa responden dalam penelitian yang memiliki sikap positif memiliki perilaku baik, sedangkan responden dengan sikap negatif mempunyai cenderung berperilaku buruk. Hasil penelitian di Kecamatan Tembalang menunjukkan bahwa dengan tingkat pengetahuan yang bervariasi siswa SD/ MI di Kecamatan Tembalang sudah berperilaku baik dalam pengendalian vektor DBD. Variabel sikap terbukti berperan dalam pembentukan perilaku daripada variabel pengetahuan. Sedangkan hasil uji 
McNemar pada pre post test tentang DBD dan penanggulangannya dengan ovitrap dapat dilihat pada tabel 2.

Tabel 2. Hasil Uji McNemar Pre dan post test tentang DBD pada Santri Kelas VIII dan IX Pondok Pesantren Al Falah Putera Kota Banjarbaru (n=96)

\begin{tabular}{lc}
\hline Variabel & Exact-Sig (2-sided) \\
\hline Pengetahuan & $.018^{*}$ \\
Sikap & $.033^{*}$ \\
Tindakan & $.000^{*}$ \\
\hline
\end{tabular}

Dari hasil pre dan post test dapat dilihat bahwa penyuluhan dengan metode ceramah dan diiringi dengan pemutaran video sangat bermanfaat dalam meningkatkan pengetahuan, sikap dan tindakan santri terhadap kasus DBD. Metode ceramah adalah metode yang lazim digunakan dalam penyuluhan kesehatan karena dapat diaplikasikan pada semua kelompok umur baik anakanak maupun dewasa(Arkeman, Kartini, \& Widyatama, 2020)

Hasil penelitian Waode dkk. menunjukan adanya pengaruh penyuluhan kesehatan dengan metode ceramah pada santri/siswi SD tentang penyakit DBD pada kelompok eksperimen dengan melihat adanya peningkatan pengetahuan santri setelah dilakukan penyuluhan (Wa Ode Analestariastuti, Bahar, \& Tina, 2014). Pengetahuan merupakan salah satu stimulus perubahan perilaku, di mana pengetahuan dapat diperoleh dari media cetak atau elektronik, mengikuti sosialisasi atau penyuluhan. Perubahan perilaku yang berkelanjutan terbentuk dari adanya stimulus pengetahuan (Kurniawati dkk., 2020). Diperkuat juga dengan penelitian Sunaryanti \& Iswahyuni, (2020) yang menyebutkan bahwa ada hubungan yang berarti antara pengetahuan masyarakat dengan perilaku pencegahan terhadap penyakit demam berdarah dengue di Desa Jelok, Cepogo, Boyolali.

Setelah dilakukan post test dilanjutkan dengan demonstrasi pembuatan perangkap jentik nyamuk. Para santri diarahkan ke aula tempat praktek pembuatan perangkap nyamuk. Pemateri memberikan penjelasan tentang fungsi dari alat tersebut sebelum mempraktekkan cara pembuatan alat. Saat penjelasan berlangsung santri sangat antusias. Hal ini dapat dilihat dari keseriusan mereka menyimak pejelasan dari pemateri. Tanya jawab antara pemateri dan santri terjadi saat acara berlangsung. Untuk mempermudah santri memahami cara pembuatan alat, dilakukan demonstrasi pembuatan alat di hadapan santri. Setelah selesai maka santri diarahkan untuk membuat sendiri dengan pembimbingan pemateri. Karena alat ini sangat mudah dibuat maka tidak butuh waktu lama bagi santri untuk membuat alat ini. Mulai dari memotong bahan, mengikat, mencat dan mengeringkan hasil cat semua santri dilibatkan. Pembuatan ovitrap menggunakan bahan dasar botol bekas yang mudah diperoleh santri. Tujuannya agar botol bekas dapat digunakan kembali menjadi barang yang bermanfaat, selain itu lebih mudah membuatnya dengan bahan botol plastik. Penelitian terkait penggunaan botol sebagai ovitrap pernah dilakukan dengan hasil sebesar 16,67\% berhasil memerangkap jentik nyamuk aedes dari masing-masing 18 Ovitrap(Hamzah \& Basri, 2016).

\section{KESIMPULAN}

Dari hasil kegiatan dapat disimpulkan bahwa kegiatan Pemberian penyuluhan kesehatan. tentang penyakit Demam berdarah Dengue (DBD) dan penanggulangannya efektif dalam meningkatkan pengetahuan, sikap dan tindakan santri terhadap perilaku pengendalian DBD. Santri sudah bisa membuat perangkap telur nyamuk (Ovitrap) dan memasang alat tersebut dilingkunan pesntren secara mandiri. Penggunaan botol bekas sebagai bahan ovitrap memudahkan bahan baku pembuatan ovitrap sekaligus mengurangi volume sampah plastik. Diharapkan santri yang mengikuti kegiatan ini untuk dapat mempraktekkan dan 
menyebarluaskan pengetahuan yang mereka dapatkan ketika mereka terjun ke lingkungan permukimannya masing-masing

\section{UCAPAN TERIMA KASIH}

Penulis mengucapkan terima kasih kepada Poltekes Banjarmasin yang telah memberi dukungan financial terhadap kegiatan pengabdian dan penelitian ini.

\section{DAFTAR PUSTAKA}

Adiputra, I. M. S., Siregar, D., Anggraini, D. D., Irfandi, A., Trisnadewi, N. W., Nurmalita, M. H., ... Ani, M. (2021). Statistik Kesehatan: Teori dan Aplikasi. Yayasan Kita Menulis.

Arkeman, H., Kartini, K., \& Widyatama, H. G. (2020). Penyuluhan dengan metode ceramah dan media digital untuk meningkatkan pengetahuan tentang demam berdarah. JUARA: Jurnal Wahana Abdimas Sejahtera, 1(2), 109-121. doi: 10.25105/juara.v1i2.5636

Asniar, Kamil, H., \& Mayasari, P. (2020). Pendidikan dan Promosi Kesehatan. Syiah Kuala University Press.

Hamzah, E., \& Basri, S. (2016). Perbedaan Ovitrap Indeks Botol, Ember dan Port Mosquito Trap sebagai Perangkap Nyamuk Aedes sp. Di Area Kantor Kesehatan Pelabuhan Kelas II Samarinda Wilayah Kerja Sangatta Kabupaten Kutai Timur. HIGIENE: Jurnal Kesehatan Lingkungan, 2(3), 155-158. Diambil dari http://journal.uinalauddin.ac.id/index.php/higiene/article/view/1825

Kemenkes RI. (2017). Situasi Penyakit Demam Berdarah di Indonesia Tahun 2017. Diambil 1 November 2021, dari Kemkes.go.id website: https://www.kemkes.go.id/article/view/19011500007/situasi-penyakit-demam-berdarahdi-indonesia-tahun-2017.html

Kurniawati, R. D., Sutriyawan, A., \& Rahmawati, S. R. (2020). Analisis Pengetahuan dan Motivasi Pemakaian Ovitrap Sebagai Upaya Pengendalian Jentik Nyamuk Aedes Aegepty. Jurnal Ilmu Kesehatan Masyarakat, 9(04), 248-253. doi: 10.33221/jikm.v9i04.813

Latifa, K. N., Arusyid, W. B., Iswidaty, T., \& Sutiningsih, D. (2013). Pengaruh Ovitrap Sebagai Monitoring Keberadaan Vektor Aedes sp di Kelurahan Bulusan Kecamatan Tembalang Kota Semarang. Jurnal Ilmiah Mahasiswa, 3(1), 26-29. Diambil dari https://ejournal.undip.ac.id/index.php/jim/article/view/10868

Lima, J. B. P., Da-Cunha, M. P., Júnior, R. C. D. S., Galardo, A. K. R., Soares, S. D. S., Braga, I. A., ... Valle, D. (2003). Resistance of aedes aegypti to organophosphates in several municipalities in the state of Rio de Janeiro and espírito santo, brazil. The American Journal of Tropical Medicine and Hygiene, 68(3), 329-333. doi: 10.4269/ajtmh.2003.68.329

Polson, K. A., Curtis, C., Seng, C. M., Olson, J. G., Chantha, N., \& Rawlins, S. C. (2002). The Use of Ovitraps Baited with Hay Infusion as a Surveillance Tool for Aedes aegypti Mosquitoes in Cambodia. 26, 7.

Pujiyanti, A., Pratamawati, D. A., \& Trapsilowati, W. (2016). Hubungan Pengetahuan, Sikap, dan Perilaku dalam Rangka Pengendalian Vektor DBD pada Siswa Sekolah Dasar di Kecamatan Tembalang, Semarang. Media Penelitian Dan Pengembangan Kesehatan, 26(2), 85-92. doi: 10.22435/mpk.v26i2.4163.85-92

Sithiprasasna, R., Mahapibul, P., Noigamol, C., Perich, M. J., Zeichner, B. C., Burge, B. ... Coleman, R. E. (2003). Field Evaluation of a Lethal Ovitrap for the Control of Aedes aegypti (Diptera: Culicidae) in Thailand. Journal of Medical Entomology, 40(4), 455-462. doi: 10.1603/00222585-40.4.455

Sunaryanti, S. S. H., \& Iswahyuni, S. (2020). Hubungan antara pengetahuan dan sikap terhadap perilaku dalam pengendalian vektor demam berdarah dengue (DBD) di Desa Jelok Cepogo Boyolali. Avicenna : Journal of Health Research, 3(1), 92-104. doi: 10.36419/avicenna.v3i1.347

Wa Ode Analestariastuti, Bahar, H., \& Tina, L. (2014). Perbedaan pengaruh penyuluhan kesehatan dengan metode cerita dan ceramah terhadap pengetahuan, sikap dan tindakan siswa SD 
tentang penyakit DBD | media kesehatan masyarakat indonesia. Media Kesehatan Masyarakat Indonesia, 10(1), 8-15. Diambil dari https://journal.unhas.ac.id/index.php/mkmi/article/view/471

Wiguna, R. I., Menap, Asmawariza, L. H., Husen, L. M. S., Pa'ni, D. M. K., Yulisutomo, S., \& Apriani, L. A. (2021). Pemberdayaan Siswa Melalui Penerapan Program Health Promotion Model Sebagai Upaya Pencegahan Covid-19. Dinamisia : Jurnal Pengabdian Kepada Masyarakat, 5(4). doi: 10.31849/dinamisia.v5i4.7176

Zeichner, B. C., \& Perich, M. J. (1999). Laboratory testing of a lethal ovitrap for Aedes aegypti. Medical and Veterinary Entomology, 13(3), 234-238. doi: 10.1046/j.1365-2915.1999.00192.x

Zubaidah, T., Erminawati, E., \& Ratodi, M. (2020). Ovitrap Modification in Improving the Ability of Aedes Sp. Egg Trapping in Banjarbaru City. Jurnal Kesehatan Lingkungan, 12(4), 235-243. doi: 10.20473/jkl.v12i4.2020.235-243 